How to Cite

Venkateswarlu, P. (2019). Prospects and problems of tourism in india. International Journal of Business, Economics \&

Management, 2(1), 38-41. https://doi.org/10.31295/ijbem.v2n1.65

\title{
Prospects and Problems of Tourism in India
}

\author{
P. Venkateswarlu \\ Chebrolu Engineering College, India \\ Email: venkateswarlu@gmail.com
}

\begin{abstract}
The tourism ministry has proposed to create a 'Land Bank' by acquiring land for building hotels in public-private partnership on a built, operate and transfer basis. The Railways has also decided to utilize its land inventory for hotels. The Indian Railways Catering and Tourism Corporation is planning to set up 100 budget hotels across the country. With a view to encouraging high-end tourism in the country, the government has identified five parts for developing as cruise tourism hubs. The ports identified are Mumbai, Mormugao, New Mangalore and Kochi on the west coastline, and Tuticorin on the east coastline. The tourism ministry would also extend assistance for procurement of cruise vessels or boats for promotion of this new tourism initiative. The government is contemplating creating a tourism infrastructure fund with a corpus of \$1-3 billion. It is expected to be financed by way of loans from multilateral institutions such as the Asian Development Bank (ADB). Infrastructure Leasing \& Financial Services (IL \& FS) is advising the government on the concept plan. The entry of low-cost airlines has provided a fillip to the tourism industry. However, India's tourism industry must concentrate on encouraging Indian citizens to holiday within the country too.
\end{abstract}

Keywords---government, hotel, ministry, promotion, tourism.

\section{Introduction}

A late riser, India is slowly but surely awakening to its tourism potential. With tiny countries like Singapore, Thailand, and Malaysia already major tourist destinations, India has to struggle to market itself to the world tourists. For a long time, tourism has been treated as a leisure activity of the rich and a somewhat unnecessary distraction for the poor in India. Hence, no concerted efforts were made to develop tourism as an industry in the country. The tourism industry encompasses accommodation, travel, transport, leisure, and entertainment and offers immense employment potential at almost all levels.

\section{Prospects Ahead}

Tourism is an activity with very strong backward and forward linkages. Travelers spend money to enjoy a variety of goods, services, and experiences. The income and employment generating capacity of this sector are immense. A given investment in tourism sector generates more employment and income than those generated by the same investment in other important sectors of the economy. In 2006, tourism, as an industry offered employment to 41.8 million people, and accounted for 5.9 percent of the tourism benefits, are conferred on all classes, sections, and regions (Henderson, 2007; Majumdar et al., 2006; Todd, 2011).

India's tourism sector is projected to grow at 8.8 percent ahead of China's over the next 10 years. According to WTTC, capital investment in the Indian tourism sector is expected to touch the $\$ 121.4$ billion mark in 2024 . This will be about 7.8 percent of the total investment received by the country in that year.

As a result of 'Incredible India' campaign, the foreign tourist arrivals increased to 44,915 in 2006, up from 39, 28,610 in 2005 , and $64,57,477$ in 2014 . The foreign exchange earnings from tourism were Rs. 216,030 million in 2014, Rs. 251,720 million in 2005 and 296,030 million in 2006. The number of Indian nationals going abroad is also rising. It was 1.9 million in 1991, 4.1 million in 1999, and 7.2 million in 2014.

ISSN 2632-9476

Received Jan 20, 2019 / Accepted Jun 18, 2019 / Published Jul 05, 2019 
Tourism has seen a 14 percent growth in 2006-07, accounting for a Forex inflow of \$14 million. Around 4.4 million foreign tourists arrived in India in 2006-07. It must be noted that India is best suited for all kinds of tourism rural, cultural, eco-tourism, spiritual, sports and adventure tourism. Yet, the tourism economy in India accounts for only 5.6 percent of the GDP.

\section{Types of Tourism}

In India, the service sector is growing very fast. It now accounts for 55 percent of the GDP. India has made rapid progress in respect of biotechnology and IT related services. It has now become famous for healthcare too. Medical tourism is a concept that is attractive to visitors who love combining well-being and lifestyle healthcare services with a strong desire to travel overseas. With the cost of medical care being about 10 times cheaper in India, health tourism is also emerging as an important segment (Astawa et al., 2017; Suniastha Amerta, 2017; Pemayun et al., 2017).

It is estimated that medical tourism can alone contribute a good sum of Rs 5000 million to Rs 100,000 million of additional revenue by way of super-specialty hospitals by the year 2012. India can earn over $\$ 2$ billion annually form medical tourism. India's healthcare industry is growing fast at 30 percent annually. The Indian medical sector is attracting many foreign patients. They are coming to India for bypass surgeries, dental problems, orthopedic ailments, and even plastic surgery. A primary reason for this is cost-effectiveness. For instance, open heart surgery costs $\$ 4,500$ in India, whereas in other healthcare destinations, it may cost around $\$ 18,000$. Analysts say, around $1,50,000$ medical tourists visited India in 2005 . The number is likely to go up by 15 percent a year.

According to government sources, the country's $\$ 17$ billion a year healthcare industry could grow at 13 percent annually during the next five years. Medical tourism is said to be growing at 30 percent annually. It could provide the biggest boost to the healthcare industry and become a $\$ 2$ billion industry in the next five years. The island nation of Singapore is focusing on medical tourism. Its three agencies-the Economic Development Board (EDB), Singapore Tourism Board (STB) and the International Enterprise Singapore (IES) have joined hands to form a new initiative called Singapore Medicine to transform the nation as Asia's leading two-in-one destination for healthcare services and tourism (Pemayun et al., 2018; Amerta, 2017; Umrah et al., 2018).

\section{Eco-Tourism}

Eco-tourism is a purposeful journey to nature's lap within a country to understand its natural and cultural history. It is the management of ecology in such a way as to obtain maximum pleasure with an eye on conservation needs. Countries like Kenya, Costa Rice, Canada, and the United State have made concerted efforts to promote eco-tourism. Eco-tourism also involves the participation of the local community in nature tourism projects. Ecosystems have to become major eco-tourism centers. These include biosphere reserves, mangroves, coral reefs, deserts, mountains and forests, flora and fauna, lakes and rivers and caves.

\section{Rural Tourism}

In a country like India, rural tourism deserves special attention. Rural tourism signifies the tourist's interest in the customs of the indigenous and exotic people.

Foreign tourists are deeply interested in local customs, festivals, dances, rituals and in fact, the very lifestyle of the indigenous people intrigues them. Rural tourism development is community-based. Of course, rural environments are not to be spoilt. It needs to be protected and promoted. Rural tourism benefits the local community in more than one way. But, crass commercialization of rural tourism is not desirable. Rural tourism should help revive local peoples interest and pride in their culture, traditions, and values. The ministry of tourism is in the process of identifying a minimum of 100 villages in India to be developed under a new scheme to promote rural tourism. Some villages are rich in arts and crafts. The ministry has identified 71 such villages and has allotted Rs. 50lakh to each such village. The UNDP is providing an additional fund of Rs 20 to 36 lakh to such villages for the capacity building while the rest would be funded by the Ministry.

\section{Problems Facing the Industry}

It is often forgotten that in the last few years, more Indians traveled abroad than to the inflow of foreign visitors, leading to a net outflow of foreign exchange. Our tourism plans keep in view only one class - the foreigners. Hence, we give more importance to airports than railway stations and bus terminals. Luxury hotels get priority over budget accommodation. 
The progress of the tourism industry is tardy. Out of the 1310 tourism projects undertaken in the tenth plan, 740 projects are still complete. Because of high land price, there are more five-star hotels than budget hotels, making India a high-cost deluxe destination. Ideally, 15 percent of the cost of a hotel should be land price. However, in India, the land price goes up to 55 percent on average.

In India, 21 paise goes to the tax kitty in every rupee a tourist spends. This incidence of taxation is on the high side. It is estimated that a ten paise reduction can increase GDP by Rs. 1,23,000 million with additional tax revenue of Rs. 460 million.

According to the Tourism Ministry, the country has about 1.2 million hotel rooms of which only 7 percent (about $80,000)$ are star category. Approximately, 60,000 more hotel rooms are needed within the next three to four years to cater to the growing number of foreign and Indian tourists. It needs to be noted that the average duration of stay of a tourist in Singapore is about 5 days as against 26 days in India. The compound average growth rate of hotel rooms in India is only 6 percent as compared with 22 percent in China, 18 percent in Thailand and 15 percent in Malaysia.

\section{Suggestion to Make the Industry Attractive}

Of course, some efforts have been made by the Indian government to boost tourism activity. The center has already identified 50 projects with an estimated expenditure of $\$ 298$ million. The projects include the construction of new grade separations, flyovers, and bridges besides, improvement of some major linking roads.

The nature of tourism activity is such that even the state governments ought to have control over this vital sector. Of course, there must be proper coordination between the Centre and the states in toning up the image of tourism. There is a strong case of rationalizing the multiple taxes imposed on various goods and services. Sustainability of tourism activity, in the long run, is more important than immediate gains. We should sim at the meaningful partnership between public and private agencies because financing and maintenance of tourism-related infrastructure are important (Pemayun et al., 2019; Geria et al., 2018).

In the Tenth Plan, the existing tourism infrastructure schemes were merged into two new schemes, namely, the integrated Development of Tourism Circuits and Product Infrastructure and Destination Development. These projects are now being fully funded by the central government. State governments provide land and external infrastructure.

The government launched the 'Incredible India' campaign in 2004. It has produced some positive results. The government has also identified 17 tourist circuits across the country where the tourism infrastructure would be developed.

It also liberalized the rules governing charter flights. Allowing inbound charter flights to touchdown at all international airports and permission to Indian citizens to use such charters would definitely help tourism. According to estimates, a two-week tour of Europe would cost only Rs. 85,000 per person under the new business rules, while the earlier estimate was Rs 1.25 lakh. Similarly, a nine-day tour of the Far East could be undertaken for just Rs. 32,000 as compared to the previous estimate of Rs 45,000 .

The tourism ministry has proposed to create a 'Land Bank' by acquiring land for building hotels in public-private partnership on a built, operate and transfer basis. The Railways has also decided to utilize its land inventory for hotels. The Indian Railways Catering and Tourism Corporation is planning to set up 100 budget hotels across the country. With a view to encouraging high-end tourism in the country, the government has identified five parts for developing as cruise tourism hubs. The ports identified are Mumbai, Mormugao, New Mangalore and Kochi on the west coastline, and Tuticorin on the east coastline. The tourism ministry would also extend assistance for procurement of cruise vessels or boats for promotion of this new tourism initiative.

The government is contemplating creating a tourism infrastructure fund with a corpus of $\$ 1-3$ billion. It is expected to be financed by way of loans from multilateral institutions such as the Asian Development Bank (ADB). Infrastructure Leasing \& Financial Services (IL \& FS) is advising the government on the concept plan. The entry of low-cost airlines has provided a fillip to the tourism industry. However, India's tourism industry must concentrate on encouraging Indian citizens to holiday within the country too. 


\section{References}

Amerta, I. M. S. (2017). Community-based tourism development. International Journal of Social Sciences and Humanities, 1(3), 97-107. https://doi.org/10.29332/ijssh.v1n3.60

Astawa, I. N., Mantra, I. B. N., \& Widiastuti, I. A. M. S. (2017). Developing communicative English language tests for tourism vocational high school students. International Journal of Social Sciences and Humanities, 1(2), 5864. https://doi.org/10.29332/ijssh.v1n2.43

Geria, A. A. G. A., Maheswari, A. I. A., \& Pemayun, A. A. G. P. (2018). Social media as promotion trend for increasing tourist visit towards digital era. International Journal of Social Sciences and Humanities, 2(3), 86-94. https://doi.org/10.29332/ijssh.v2n3.204

Henderson, J. C. (2007). Corporate social responsibility and tourism: Hotel companies in Phuket, Thailand, after the Indian Ocean tsunami. International Journal of Hospitality Management, 26(1), 228-239. https://doi.org/10.1016/j.ijhm.2006.02.001

Majumdar, B., \& Bandyopadhyay, K. (2006). A Social History of Indian Football: Striving to Score. London: Routledge. https://doi.org/10.4324/9781315829814

Pemayun, A. A. G. P., \& Brata, I. B. (2018). Implementation of tourism facilities expansion to hedonism and community imaging. International Journal of Social Sciences and Humanities, 2(1), 33-42. https://doi.org/10.29332/ijssh.v2n1.76

Pemayun, A. A. G. P., \& Suderana, I. W. (2019). Shifting social and economic structural community: rapid development of tourism sector. International Journal of Social Sciences and Humanities, 3(1), 115-124. https://doi.org/10.29332/ijssh.v3n1.271

Pemayun, A. G. P., \& Maheswari, A. I. A. (2017). Economic impacts of craftsman statue on community based tourism development. International Journal of Social Sciences and Humanities, 1(3), 59-73. https://doi.org/10.29332/ijssh.v1n3.56

Suniastha Amerta, I. M. (2017). The role of tourism stakeholders at Jasri tourism village development, Karangasem regency. International Journal of Social Sciences and Humanities, 1(2), $20-28$. https://doi.org/10.29332/ijssh.v1n2.32

Todd, M. K. (2011). Handbook of medical tourism program development: developing globally integrated health systems. CRC Press.

Umrah, D. M., Mahyuni, -, \& Syahdan, -. (2018). Communication strategy for English guides: tourism area in Lombok island. International Journal of Social Sciences and Humanities, 2(3), 117-124. https://doi.org/10.29332/ijssh.v2n3.217 